\title{
Citation and Altmetric Status of Research Outputs of Tehran University of Medical Sciences During 2006-2020
}

\author{
Amir Ghasemiyan ${ }^{1}$, Fereshte Nojavan $^{2 *}$, Arezou Danaeniya ${ }^{3}$ \\ 1. Faculty of Education and Psychology, Shahid Beheshti Univeristy, Tehran, Iran \\ 2. Faculty of Education and Psychology, University of Isfahan, Isfahan, Iran \\ 3. Faculty of Education and Psychology, Allameh Tabataba'i University, Tehran, Iran
}

Received: 12 June 2021

Accepted for publication: 6 September 2021

[EPub a head of print-14 September 2021]

Payesh: 2021; 20 (5): 549- 559

\begin{abstract}
Objective(s): The purpose of this study was to investigate the citation status and presence of research outputs of Tehran University of Medical Sciences in social media in five subjects during the years 2006-2020.

Methods: The study applied scientometric and Altometric indicators. The five subject areas ("Biochemistry, Genetics and Molecular Biology ", " Pharmacology, Toxicology and Pharmaceutics ", " Immunology and Microbiology ", " Chemistry ", " Engineering ") of Tehran University of Medical Sciences was selected according to the subject classification of Scopus Citation Database. Data were extracted from Scopus, Altmetric and Scival databases. To analyze data Microsoft Excel software and SPSS 22 was used.

Results: The results showed that "Biochemistry, Genetics and Molecular Biology" had the most and "Engineering" had the least products, citation and h-index. "Engineering" and "Chemistry" had better performance in terms of the quality of research outputs according to the "Percentage of Papers Published in High-Quality Journals" and "percentage of Highly-Cited Papers" indicators. The subject area of "Immunology and Microbiology" was at a lower level in terms of citation criteria than other subject areas. About 30 percent of the outputs were on social media, receiving the most mention and bookmarking on Twitter and Mendely at all times. There was a statistically significant relationship between the number of bookmarking and the altmetric score with the number of citations received by the outputs in Scopus.

Conclusion: Social media could have a positive effect on increasing public health awareness and literacy, as well as increasing the citation of research outputs. Since the research outputs of Tehran University of Medical Sciences did not have a favorable presence on social media, it is necessary for the researchers of this university to increase their visibility and increase the citation of their outputs by actively participating and sharing their works on social media.
\end{abstract}

Keywords: Research Outputs, Tehran University of Medical Sciences, Scientometric, Altmetrics

\footnotetext{
* Corresponding author: University of Isfahan, Isfahan, Iran

E-mail: nojavan.f67@gmail.com
} 


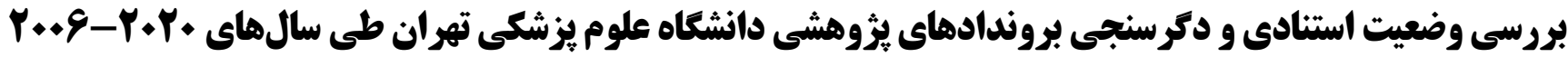

\author{
امير قاسميان'، فرشته نوجوان ‘* آرزو دانايى نيا؟ \\ 1. ا. دانشكده علوم تربيتى و روانشناسى، دانشخاه شهيد بهشتى، تهران، ايران

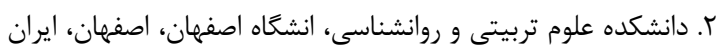

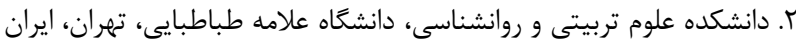

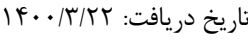

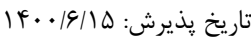

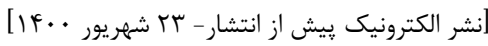 If . شريه

جكيده

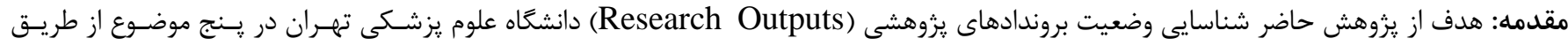

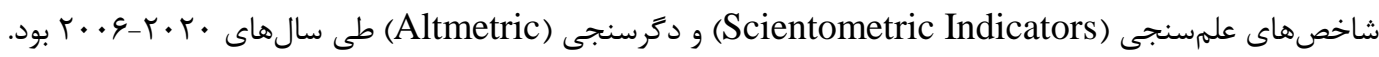

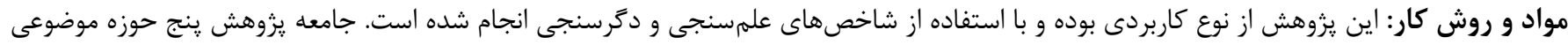

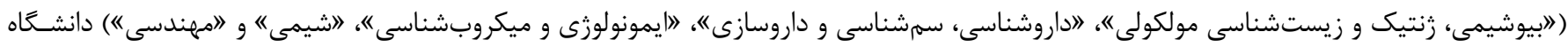

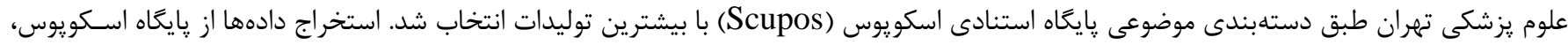

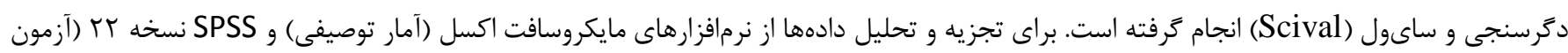

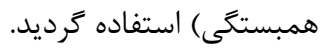

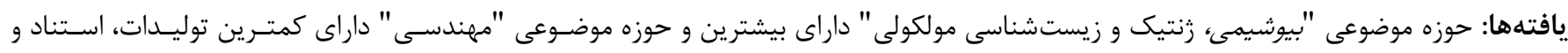

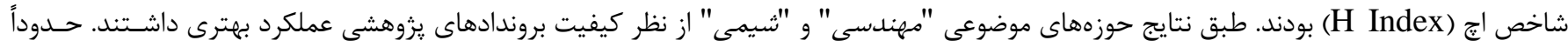

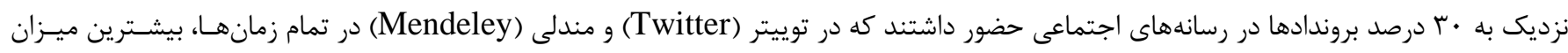

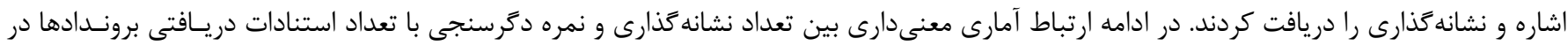
اسكويوس وجود داشت.

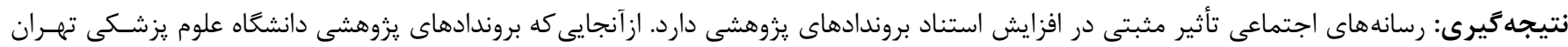

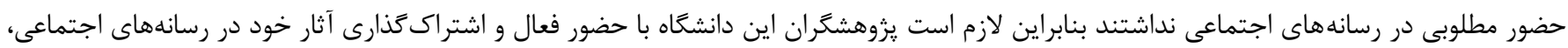

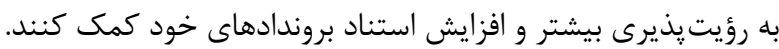
كليدوازه: بروندادهاى يُوهشى، دانشًاه علوم يزشكى تهران، علمسنجى، دكر سنجى 
طى سالهاى اخير استفاده از رسانههاى اجتماعى در جهت بهبود و

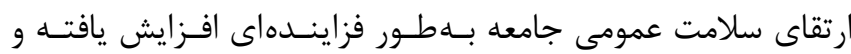

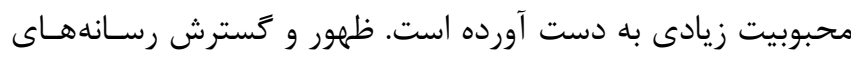
اجتماعى موجب تحول در حوزه يزشكى شده است؛ بهطـورى كـهـ بــاـ

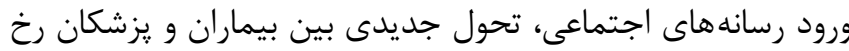

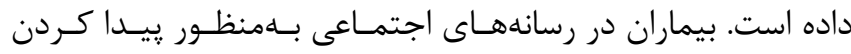

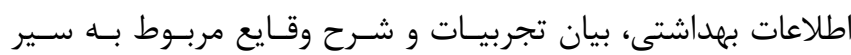

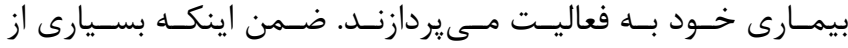
يزوهشكران و يزشكان نيز بهطور حرفـهاى از رسـانههـاى اجتمـاعى إنى براى بيدا كردن و به اشتراى كذاشتن نتـايج تحقيقـات و واطلاعـات

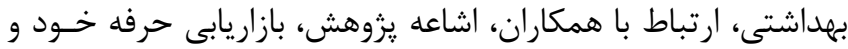

تعامل با بيماران استفاده مىنمايند [• [1].

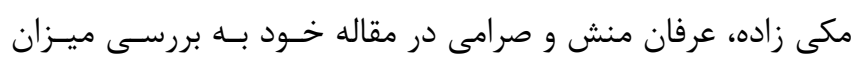

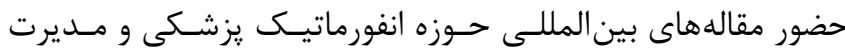

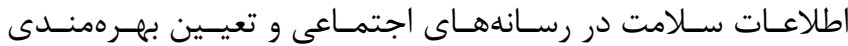

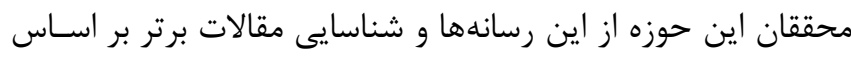

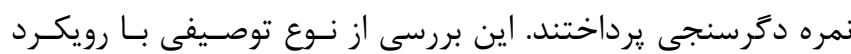

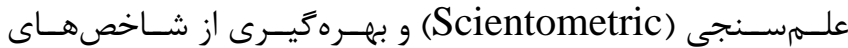

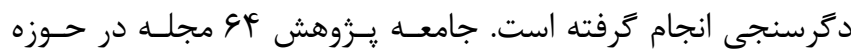

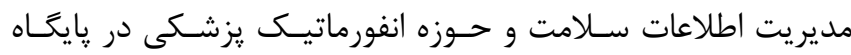
اس.جى.آر. (SJR) و اسكويوس است. يافته ها حاكى از آن بـود كـهـ

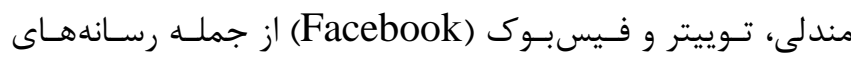

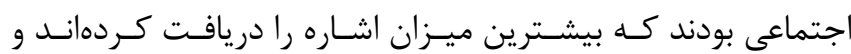

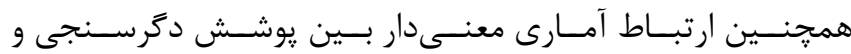

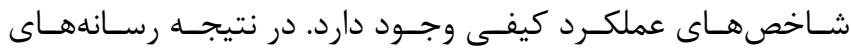

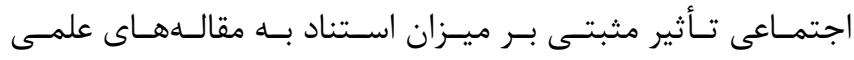

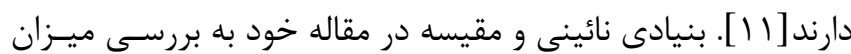

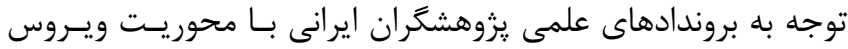

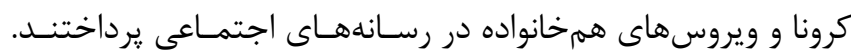

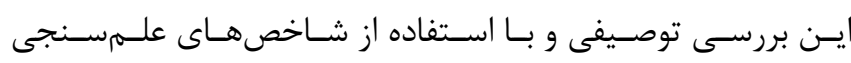
(Scientometric Indicators) جامعه يروهش شامل 9VA برونداد علمى كه طى سالهـاى مختلـف

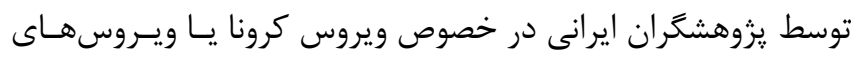

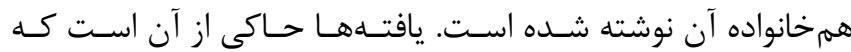

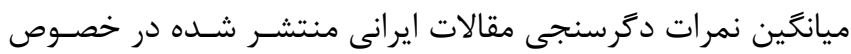

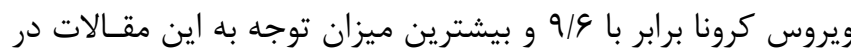

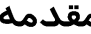

بروندادهاى يزوهشى بهعنوان يك نيـاز ضـرورى بــراى حفـظ بقــاو

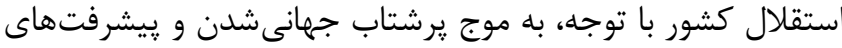

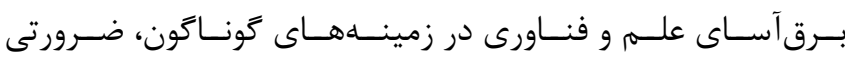
اجتنابنايذير است [1]. در دنياى كنونى كه يزوهش بهعنوان عاملى زملى براى افزايش قدرت محسوب مىشود، كشورها سعى مى كنند كميت و كيفيت بروندادهاى يزوهشى خود را افزايش دهند. علمسنجى نيـز

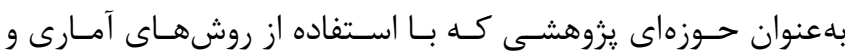

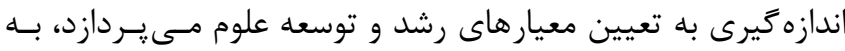

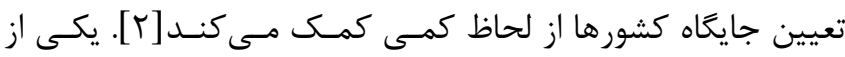

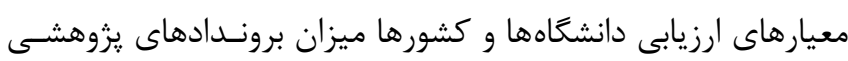

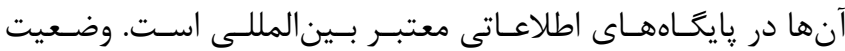

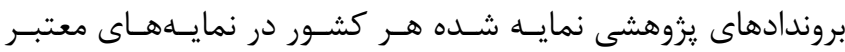

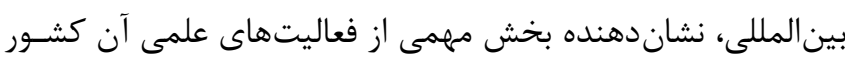

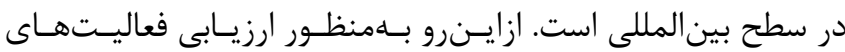
علمى، تصويرى روشن از اين وضـعيت همــواره موردتوجـهـ مـديران

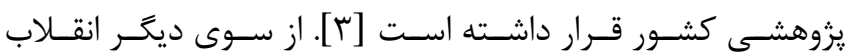
Web 2.0

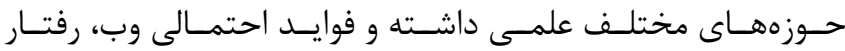
يروهشكَران را تغيير داده است. سـطح وسـيع دسترسى و كَّـترده بودن استفاده از وب سبب شده است تا يزوهشكران از اين فضا براى

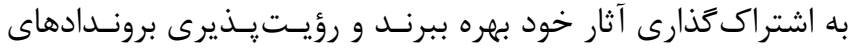

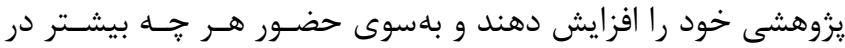

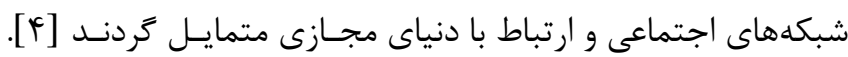

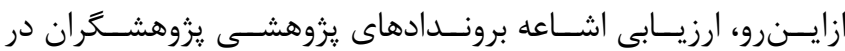

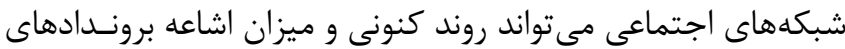

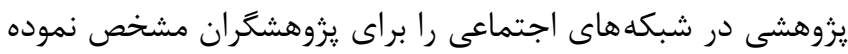

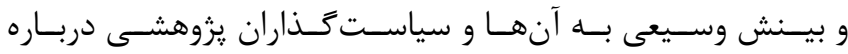

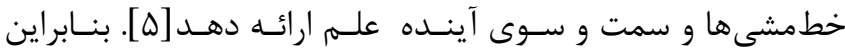

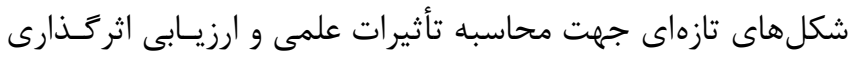
انتشارات علمى به وجود آمده است كه استفاده در سطح هر مـدرى

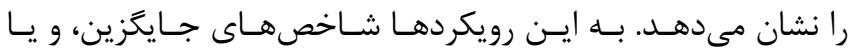

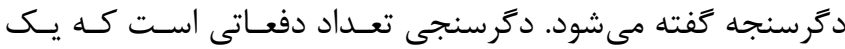

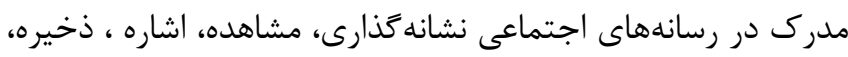
لايك، كليك يا اشتراك شده، تعداد و كيفيت نظراتى كـهـ دريافت

كرده و يا تعداد افرادى كه آن مدرى را بي إيخيرى مى كنند [9-9]. 
مجــلات لنسـت (The Lancet)، مجلــهـ يزشـكى نيوانعلنـــــ ،(The New England Journal of Medicine:NEJM)

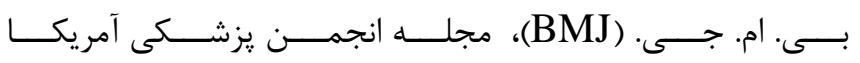
(The Journal of the American Medical Association:JAMA) داراى بيشترين تعداد مقاله و همجنين نويسندكان دو كشور جين و زاين فعالترين افراد در خصوص تأليف مقاله بـا موضـوع كوويـد 19

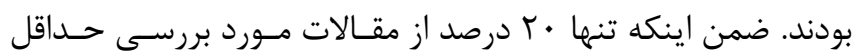
يك بار در رسانههاى مختلف مورد توجه قرار گرفتهاند. نتايج نشـان

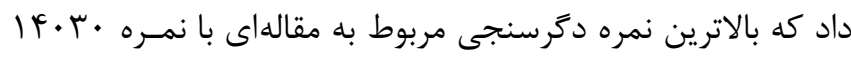

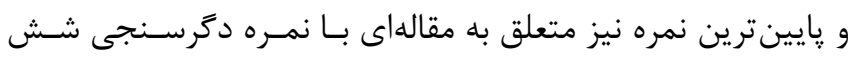

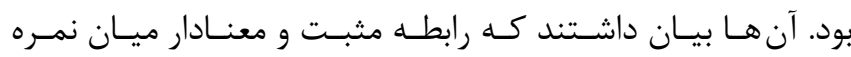

دگرسنجى مقالات و استنادهاى آن وجود دارد [• بـ].

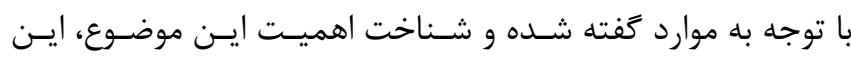

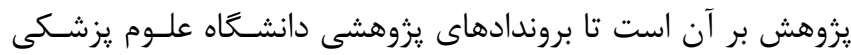

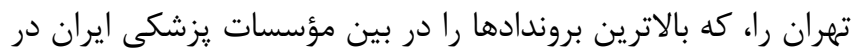

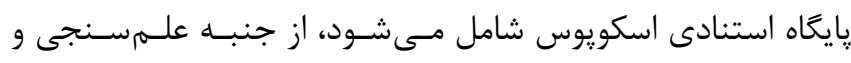

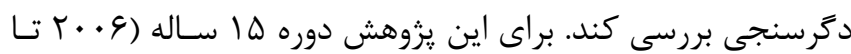

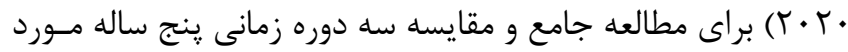

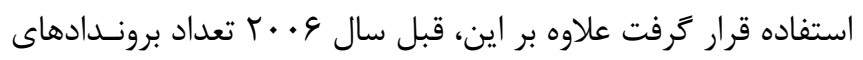

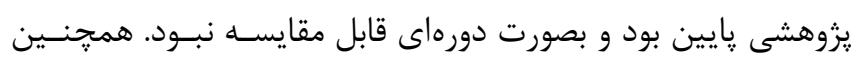

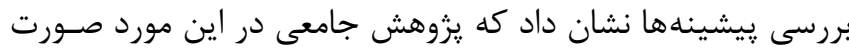

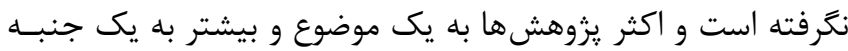

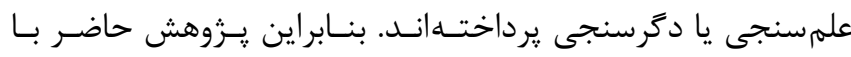

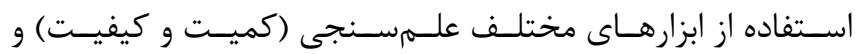

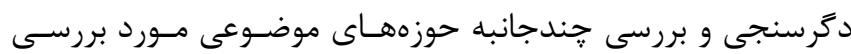

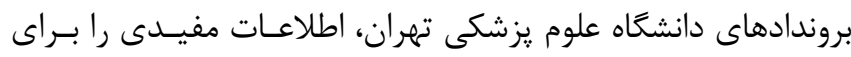

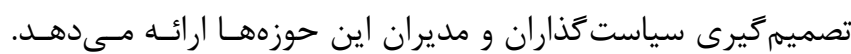

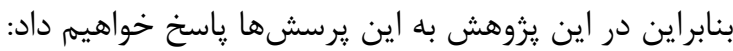

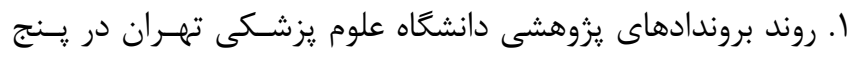

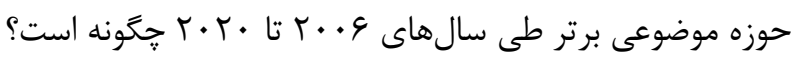

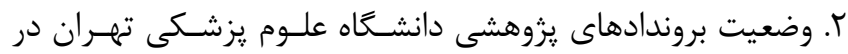

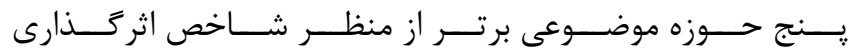
يزوهشى طى سه دوره زمانى از سالهـاى (Impact Indicators)

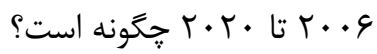
r. وضعيت بروندادهاى يزوهشى دانشگاه علوم يزشكى تهران در ينج

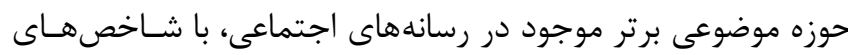

رسانه اجتماعى توييتر اتفاق افتاده اسـت [1 I]]. همجنــين از ديخـر

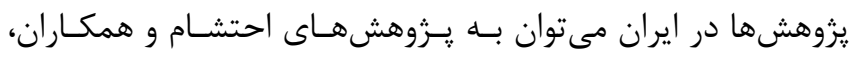

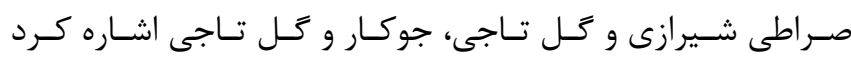

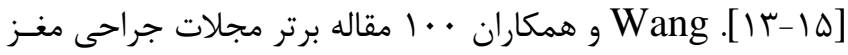

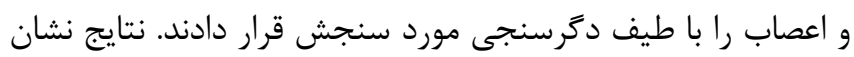

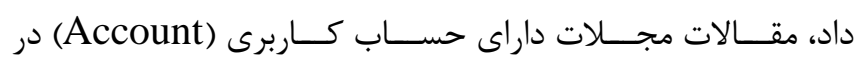
شبكههاى اجتماعى، در مقايسه با مجلات بدون حساب حاب كار كاربرى نمره

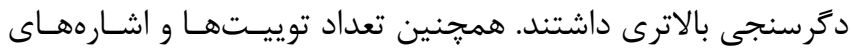

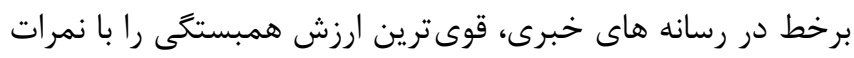

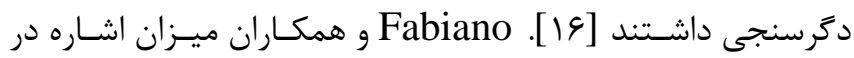

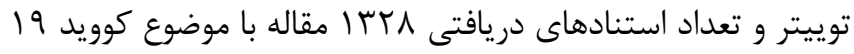

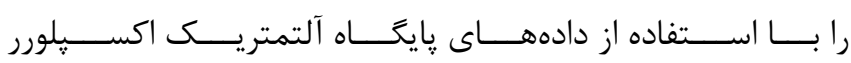
Web of Science و (Altmetric Explorer)

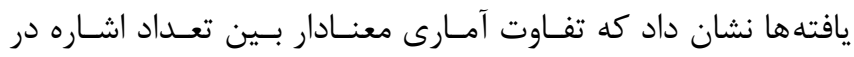
توييتر و تعداد استنادهاى دريافتى وجود دارد بهطورى كه هر مقالـه دافه

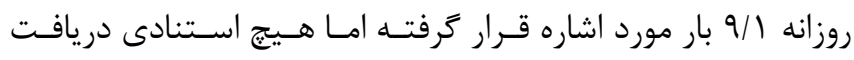

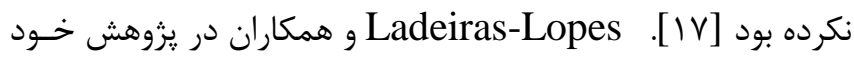

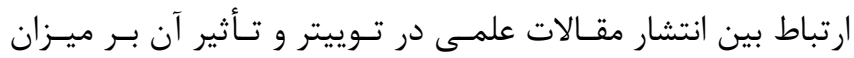
استنادات را مورد بررسى قرار دادند.

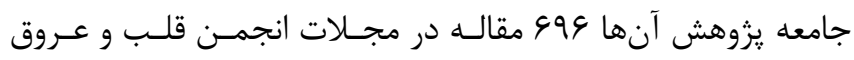
ارويا (European Society of Cardiology: ESC) در سـال

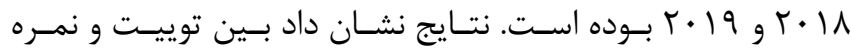

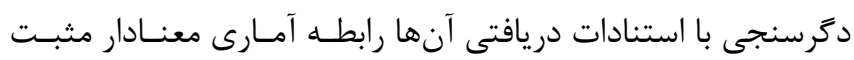

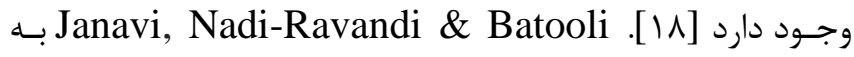
بررسى تـأثير Research Gate در افـزايش اسـتنادات و ميـزان

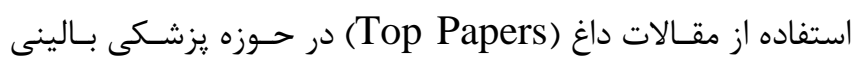

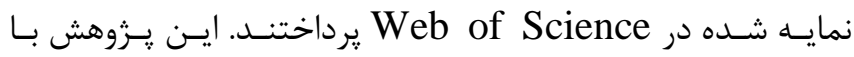
استفاده از روشهاى علمسنجى انجام شـده اسـت. نتـايج نشـان داد

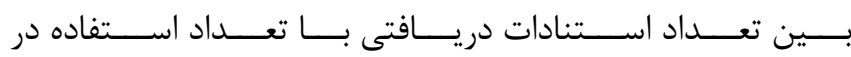
و شـاخصهـاى Rebearch of Science

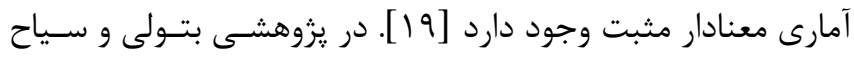

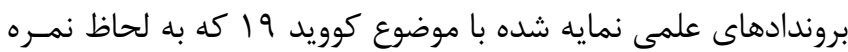

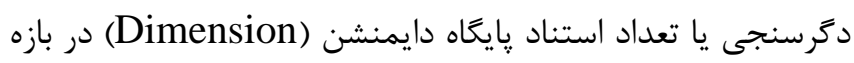

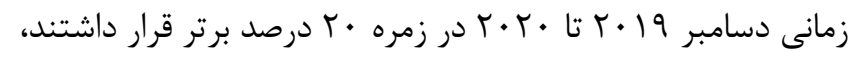

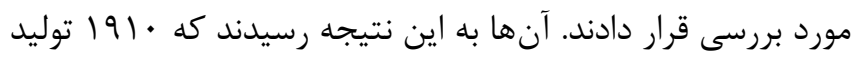

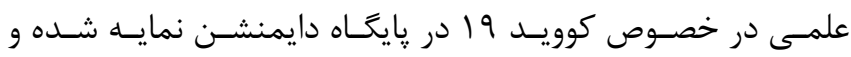


ميزان و روند رشد بروندادهاى يزوهشى در ينج حوزه موضوعى برتـر

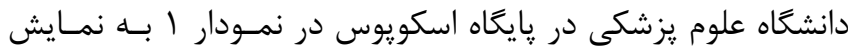

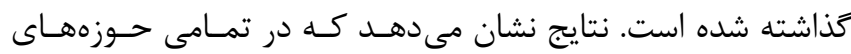

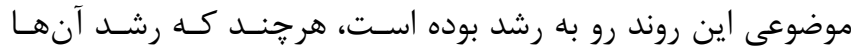

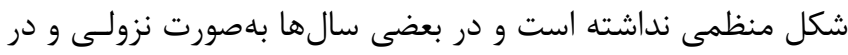

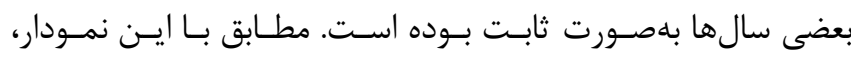

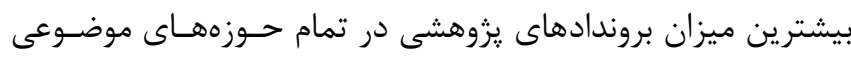

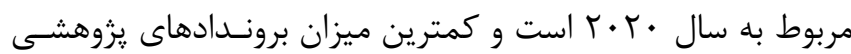

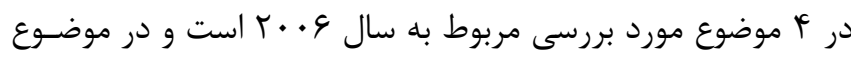

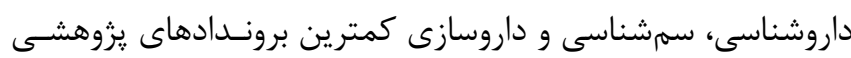

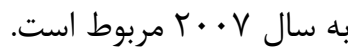

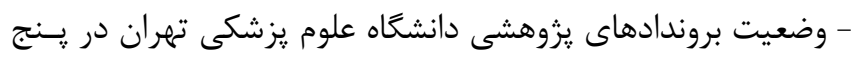

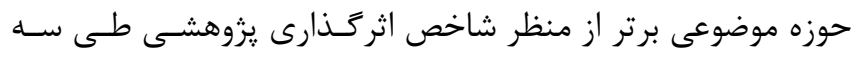

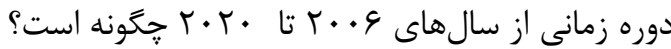

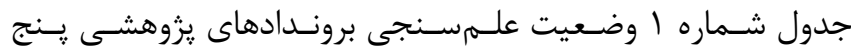

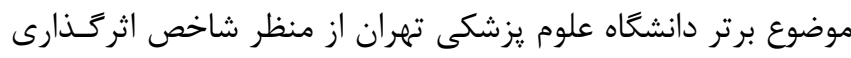

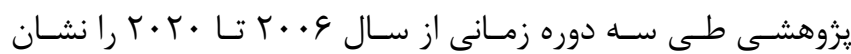

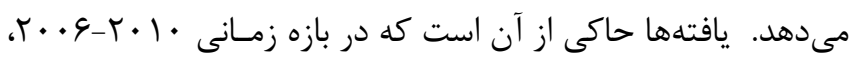

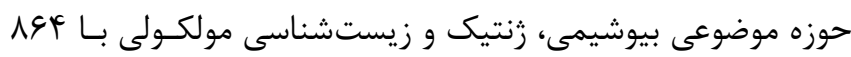

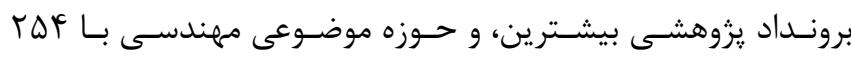

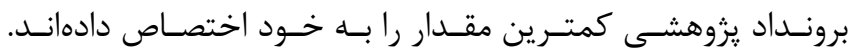

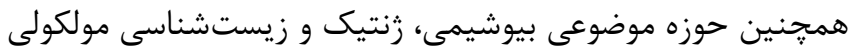

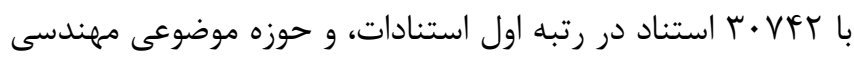

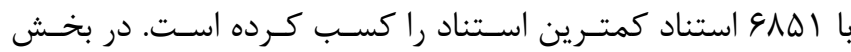

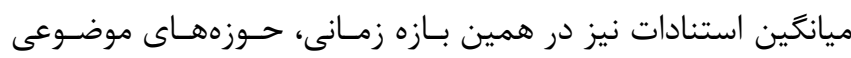

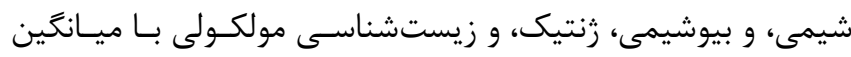

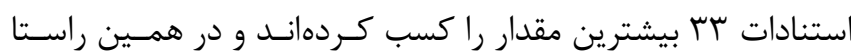

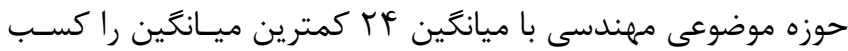
كرده است. از نظر شاخص أج نيز حوزه موضوعى بيوشيمى، زنتيك

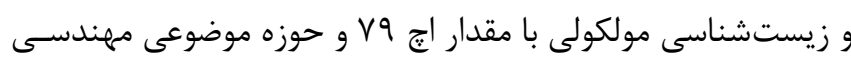
با مقدار اج بأ، بيشترين و كمترين مقدار اج را كسـب كـردهانـد. از

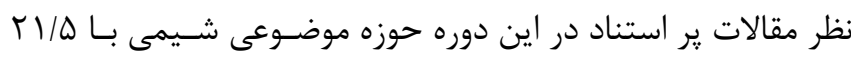

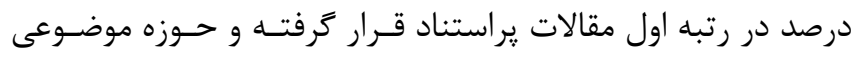

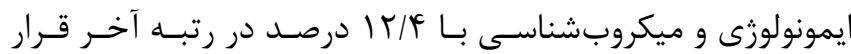
كرفته است. در بخش مقالات منتشر شده در مجلات برتر نيز حست حسوزه

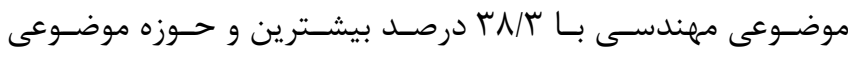

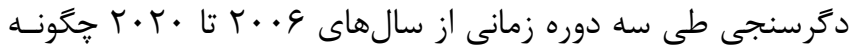

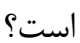

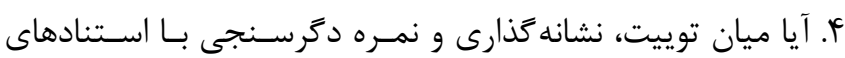

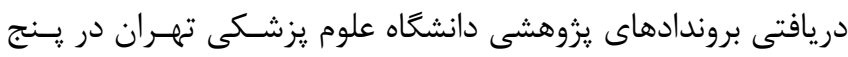

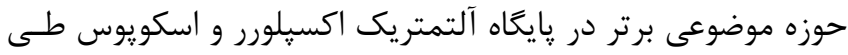

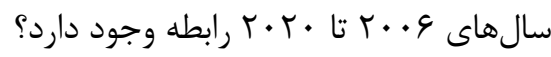

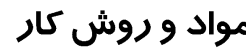

يزوهش حاضر از نوع كاربردى اسـت و بـا اسـتفاده از شـاخصهـاى

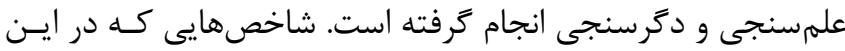
يزوهش مورد بررسى قرار گرفته است شامل استناد، ميانگين استناد

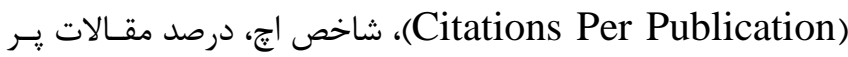

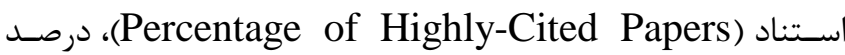

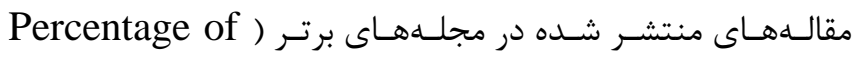
(Papers Published in High-Quality Journals

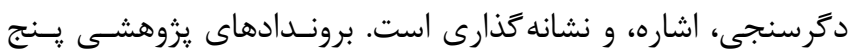

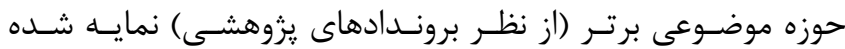

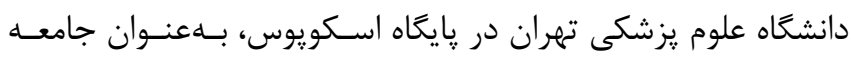

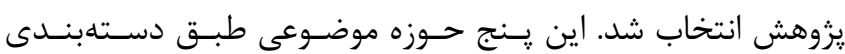

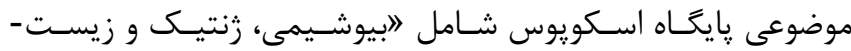

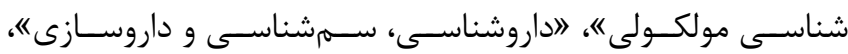

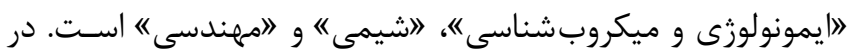

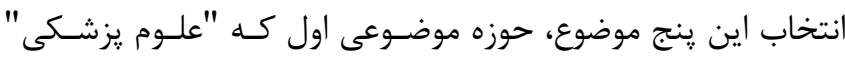

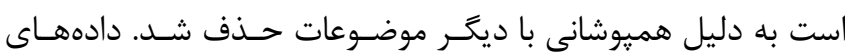

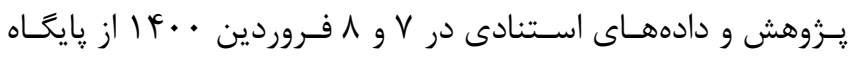

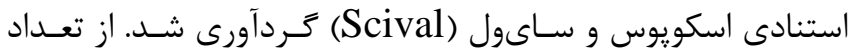

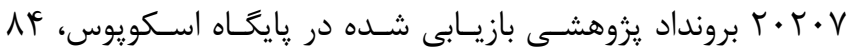

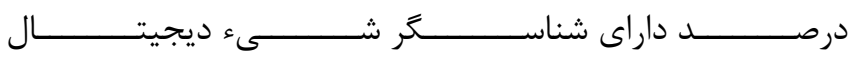
1. بودند، كـه در تـاريخ ديجين (Digital Object Identifier: DOI)

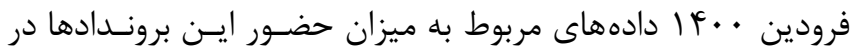

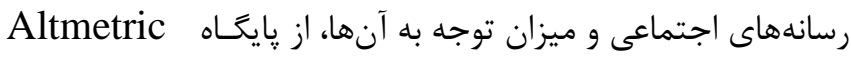
Explorer نرمافزارهاى مايكروسافت آفيس اكسل براى آمار توصيفى و 22 براى آزمون همبستگى مورد تجزيه و تحليل قرار كرفت

يافتهها

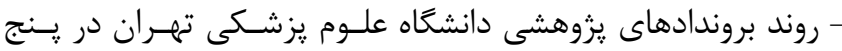

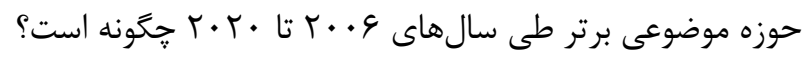


نشريه يزوهشكده علوم بهداشتى جهاددانشاهى

ايمونولوزى و ميكروبشناسى با N/D درصد كمترين مقدار را كسـب

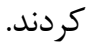

1. وضعيت بروندادهاى يزوهشى دانشكاه علوم يزشكى تهران در ينج

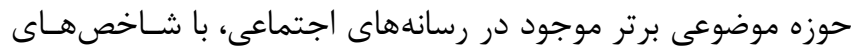

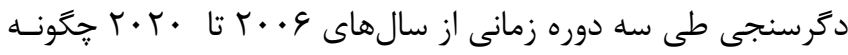

|ست؟ دكر

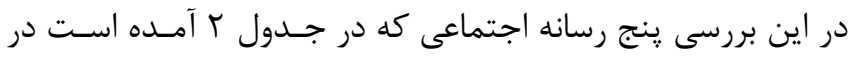

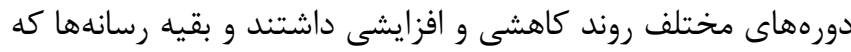

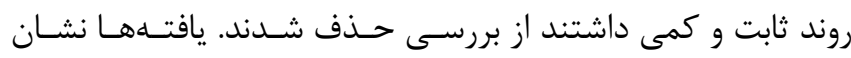

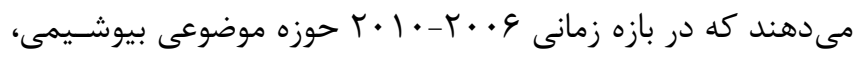

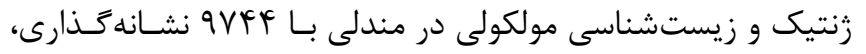

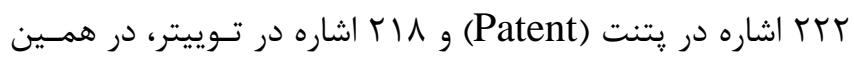

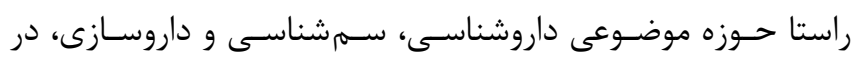

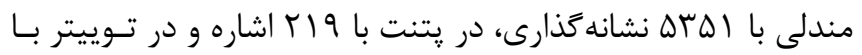

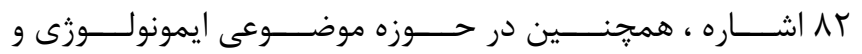

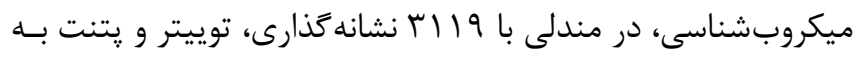

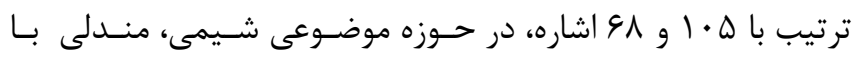
IVT

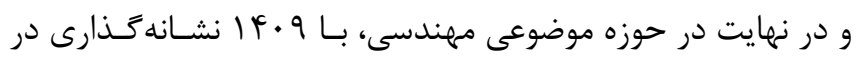

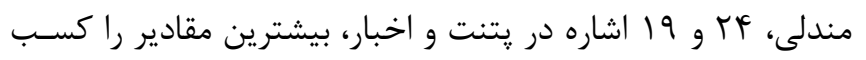

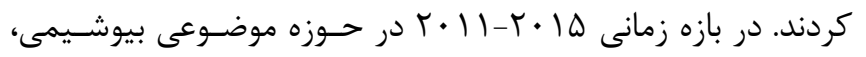

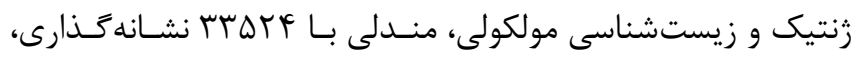

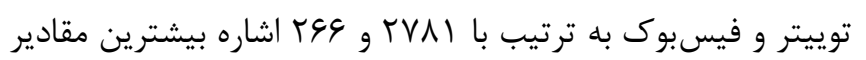

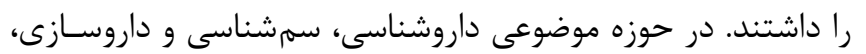

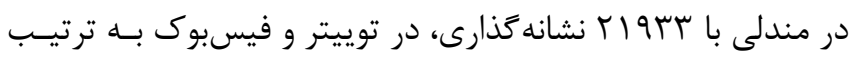

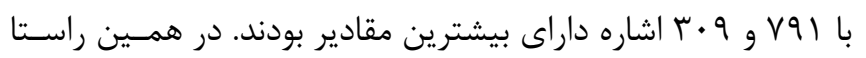

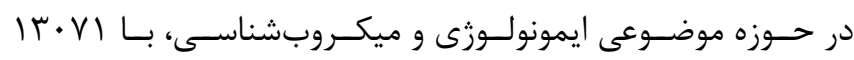

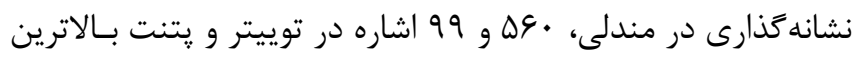

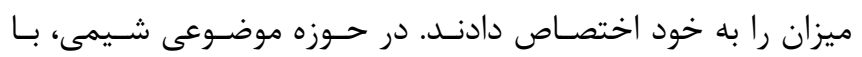

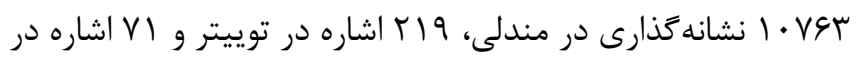

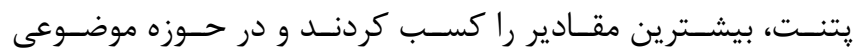

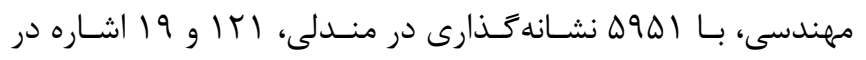

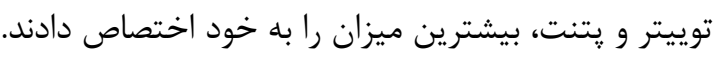

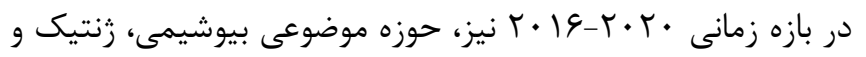

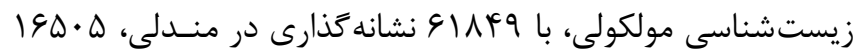

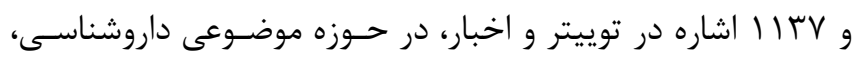

ايمونولوزى و ميكروبشناسى با ه/ د درصد كمترين مقدار را كسـب

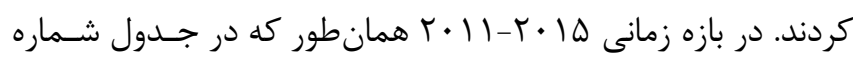

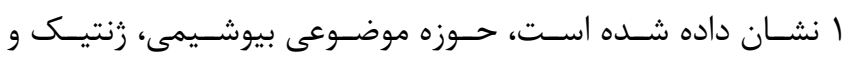

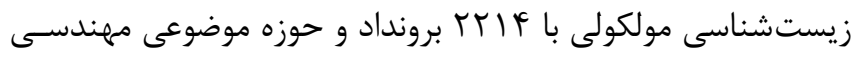

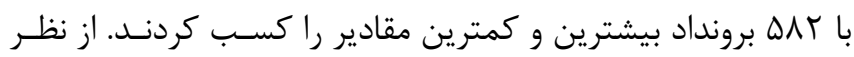

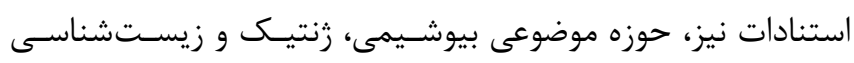

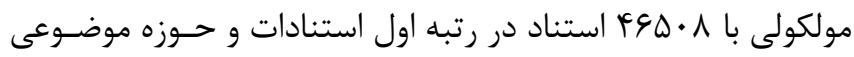

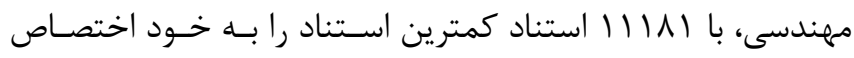

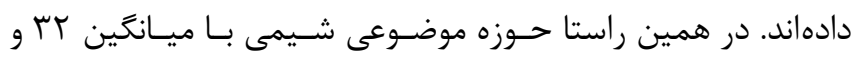

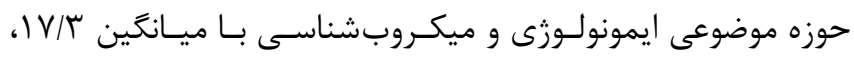

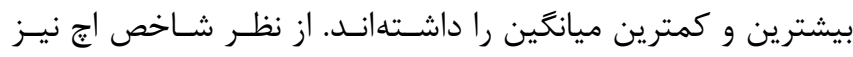

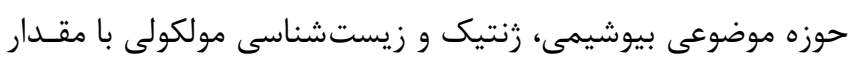

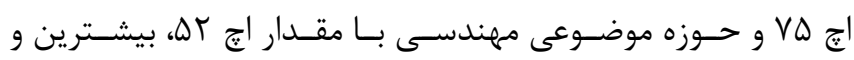

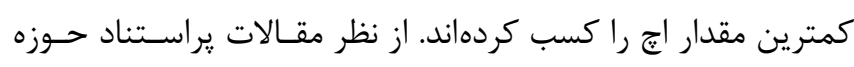

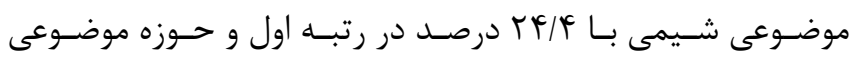

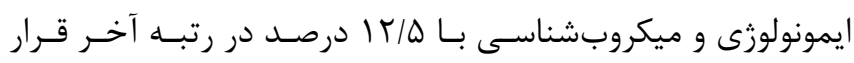

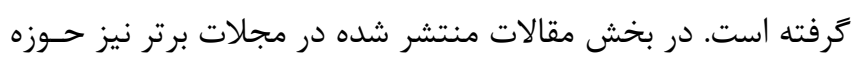

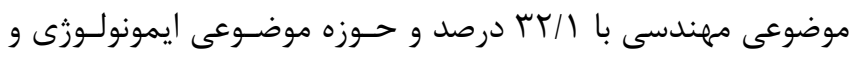

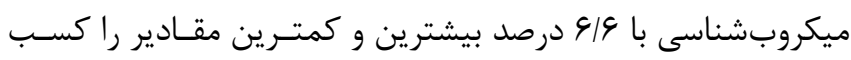

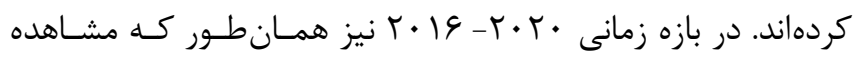

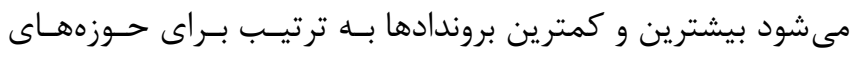

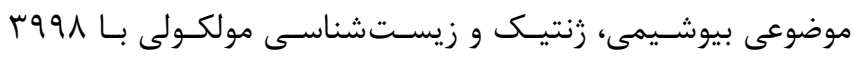

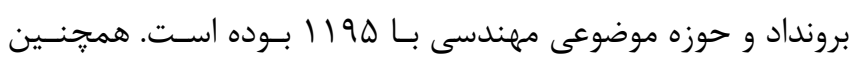

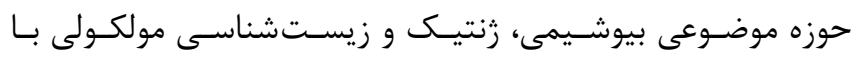

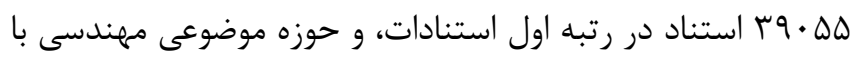

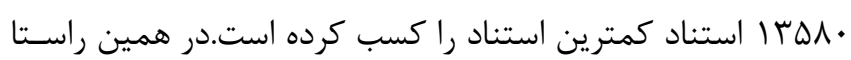

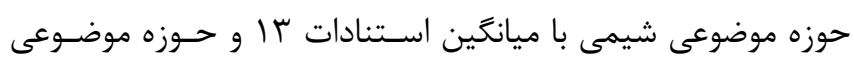

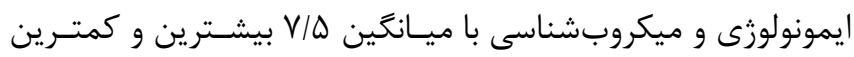

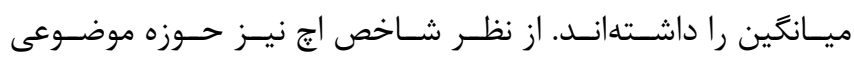
بيوشيمى، زنتيك و زيستشناسى مولكولى با مقدار أج هو هو بيشترين

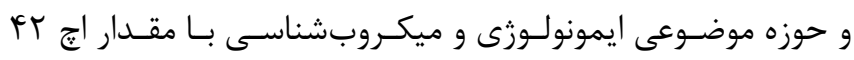

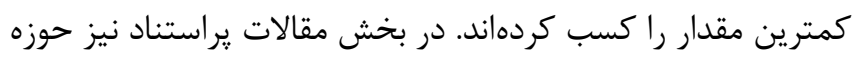

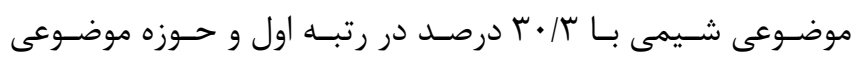

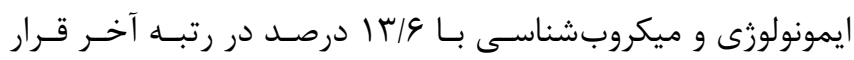

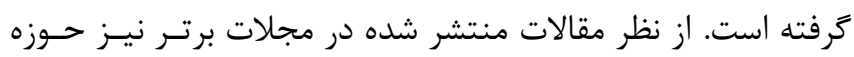

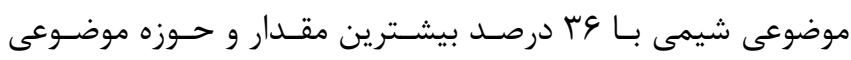


سال بيستم، شماره هنجم، مهر - آبان ••lf

ז. آيا ميان توييت، نشانه كذارى و نمـره دخرسـنجى بـا اسـتنادهاى

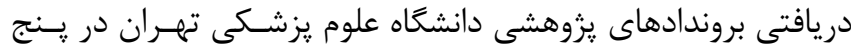

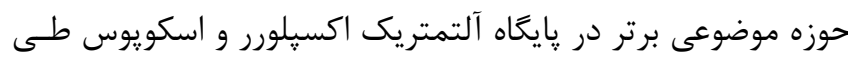

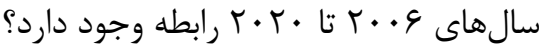

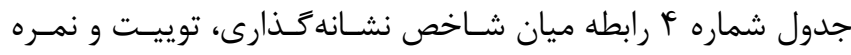

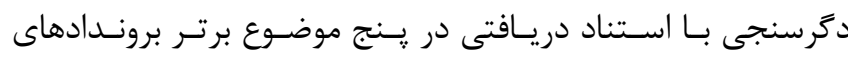

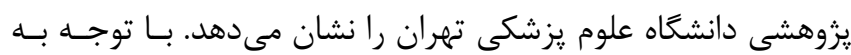

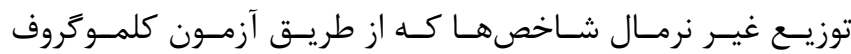

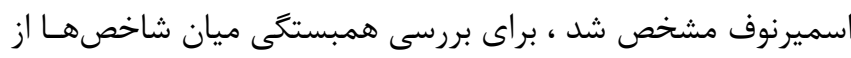

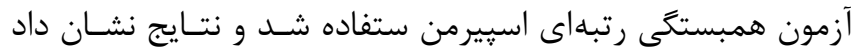

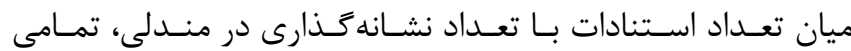

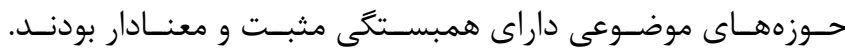

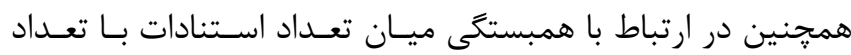

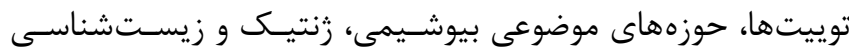

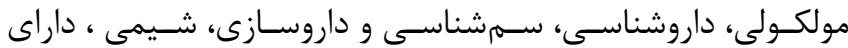

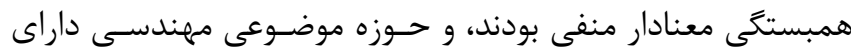

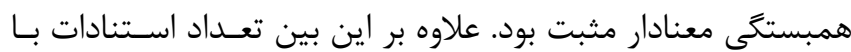

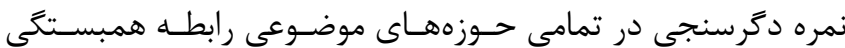

$$
\text { معنادار مثبت يافت شد. }
$$

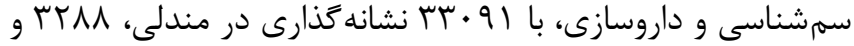

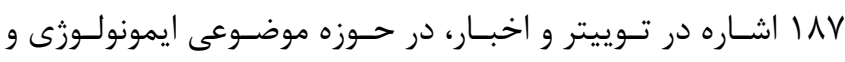

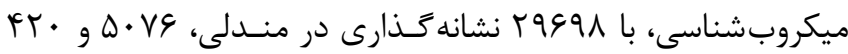

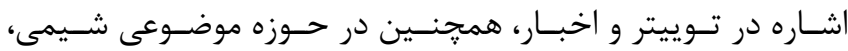

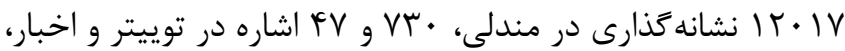

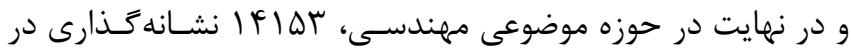

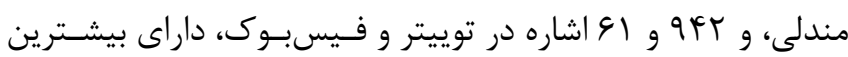
مقادير بودند. در ادامه همانطور كـه در جــدول شـماره ؟ مشـاهده

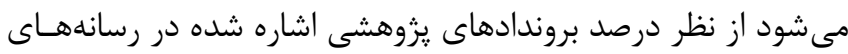

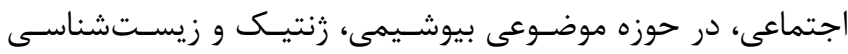

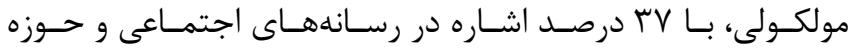

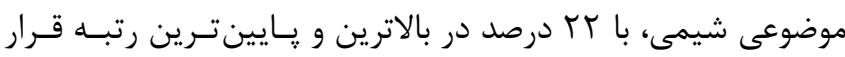

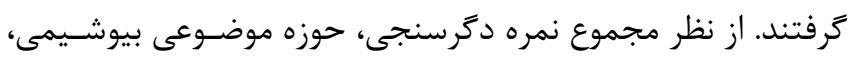

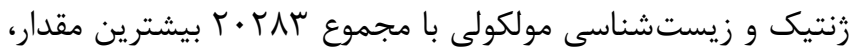
و حوزه موضوعى شيمى با لهب ا كمترين مقدار را كسب كردنـد. از

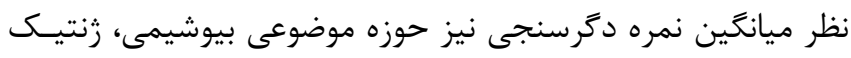

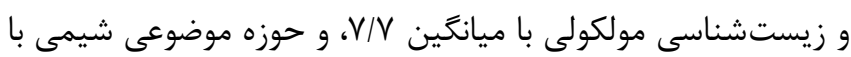
ع/ז، در رتبههاى اول و آخر قرار كرفتند.

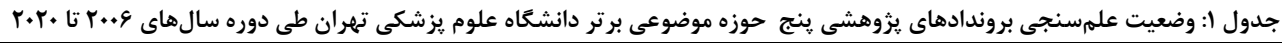

\begin{tabular}{|c|c|c|c|c|c|c|c|c|c|c|c|c|c|c|c|}
\hline \multicolumn{3}{|c|}{ مهندسى } & \multicolumn{3}{|c|}{ شيمى } & \multicolumn{3}{|c|}{ ميكروبشناسى و ايمولوزى } & \multicolumn{3}{|c|}{ داروشناسى، سمشناسى و } & \multicolumn{3}{|c|}{ زيستشيوشى، زنتيكى مولكولى } & \\
\hline $\begin{array}{l}\text {-t. T. } \\
\text { te }\end{array}$ & $\begin{array}{l}-r \cdot 11 \\
r .10\end{array}$ & $\begin{array}{l}-r \cdot 1 . \\
r . . \varphi\end{array}$ & $\begin{array}{l}-t \cdot T \cdot r \\
r \cdot r .\end{array}$ & $\begin{array}{l}-r \cdot 11 \\
r .10\end{array}$ & $\begin{array}{l}-r \cdot l . \\
r \cdot . \varphi\end{array}$ & $\begin{array}{l}\text {-t.le } \\
t \cdot r .\end{array}$ & $\begin{array}{l}-r \cdot 11 \\
r \cdot 10\end{array}$ & $\begin{array}{l}-r \cdot l \cdot \\
r . . \varphi\end{array}$ & $\begin{array}{l}\text {-r.le } \\
t \cdot r .\end{array}$ & $\begin{array}{l}-r \cdot 11 \\
r .10\end{array}$ & $\begin{array}{l}-r \cdot l . \\
r \cdot . \varphi\end{array}$ & $\begin{array}{l}-t \cdot i e \\
t \cdot r .\end{array}$ & $\begin{array}{l}-r \cdot 11 \\
r .10\end{array}$ & $\begin{array}{l}-r \cdot 1 . \\
r \cdot . \varphi\end{array}$ & \\
\hline 1190 & $\Delta \Lambda T$ & $r \Delta F$ & $14 \cdot 4$ & var & 4.9 & I9TV & $|r q|$ & pVr & TAFT & $19 \cdot 0$ & $V \Delta \Delta$ & ५१९८ & TrIF & Nat & در اسكويوس برونداد يُوهشى \\
\hline 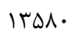 & 11111 & $9 \wedge \Delta 1$ & IVTIS & rovfq & 14.94 & $1 f \lambda \cdot V$ & rrArq & $|r \wedge 9|$ & TIITA & TrTAT & YIS.T & $r q \cdot \Delta \Delta$ & $490 \cdot 1$ & $r \cdot V k r$ & كل استنادات \\
\hline $11 / 1$ & $1 / 19$ & TF & $\pi$ & rT & r & $V / \Delta$ & $I V / T$ & ru & $N / 1$ & $19 / 9$ & $T V / F$ & $9 / 4$ & $r \cdot \pi$ & זr & ميانكَين استناد \\
\hline pq & $\Delta r$ & er & 81 & vr & ST & et & $\Delta \Delta$ & $\Delta \Delta$ & is & 91 & $9 V$ & $\Delta 9$ & VD & vq & شاخص اج \\
\hline$r \Delta / V$ & $19 / 4$ & $15 / 9$ & $r \cdot / r$ & $T \varphi / \varphi$ & $r / / \Delta$ & $1 \pi / 4$ & $1 T / \Delta$ & $\mid r / 4$ & $1 N / T$ & $I F / V$ & 19 & IN/V & $|F /|$ & $I V / T$ & شاخر استناد (· درصد مقاله هاى \\
\hline 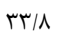 & $r T / 1$ & $r N / T$ & re & rI/9 & $r r / \Delta$ & N/Q & $9 / 9$ & $9 / \Delta$ & $r / / V$ & TN/G & $r \pi / 1$ & $r \cdot 19$ & $19 / \pi$ & $\mid N / F$ & منتشر شده در مجلههاى \\
\hline
\end{tabular}


سال بيستم، شماره ينجم، مهر - آبان ...

نشريه يزووهشده علوم بهداشتى جهاددانشحاهى

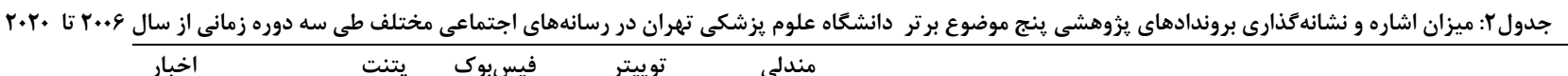

\begin{tabular}{|c|c|c|c|c|c|c|}
\hline r & trt & re & rM & qref & $r \cdot 1 \cdot-r \cdot . q$ & بيوشيمى، زنتيكى و زيستشناسى مولكولى \\
\hline 148 & IFV & T\&9 & TrAI & rTSTF & $r \cdot|\Delta-r \cdot| 1$ & \\
\hline $11 \pi v$ & rq & rat & $190 \cdot \Delta$ & $91 \wedge 49$ & $T \cdot T \cdot-r \cdot 19$ & \\
\hline re & r19 & $r v$ & $\wedge r$ & ardl & $r \cdot 1 \cdot-t \cdot \cdot q$ & داروشناسى، سمشناسى و داروسازى \\
\hline$M$ & $1 M 1$ & $r \cdot q$ & v91 & rIqזr & $r \cdot \mid \Delta-r \cdot 11$ & \\
\hline iAv & rt & 191 & TrMA & $r \mu .91$ & $r \cdot r \cdot-t \cdot 19$ & \\
\hline r & $9 \Lambda$ & 4 & $1 \cdot 0$ & r119 & $r \cdot 1 \cdot-r \cdot . c$ & ايمونولوزى و ميكروبشناسى \\
\hline r & 99 & vq & $\Delta s$. & $|r \cdot v|$ & $r \cdot|\Delta-r \cdot| 1 \mid$ & \\
\hline rr. & 11 & 191 & $\Delta \cdot v 9$ & r৭991 & $r \cdot r \cdot-r \cdot 18$ & \\
\hline . & $\Delta q$ & . & r & ivrq & $r \cdot 1 \cdot-r \cdot . \varphi$ & 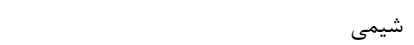 \\
\hline r) & vi & r. & r19 & 1.Var & $r \cdot|\Delta-r \cdot| 1$ & \\
\hline r & 11 & eV & $v r$. & $1 r \cdot I V$ & $r \cdot r \cdot-r \cdot 19$ & \\
\hline १ & re & . & 1 & $14 \cdot 9$ & $r \cdot 1 \cdot-r \cdot . \varphi$ & مهندسى \\
\hline v & 19 & 19 & $|r|$ & $\Delta 9 \Delta 1$ & $r \cdot|\Delta-r \cdot| 1 \mid$ & \\
\hline$\Delta \varphi$ & 11 & 91 & gRT & IfIar & $r \cdot r \cdot-r \cdot 19$ & \\
\hline
\end{tabular}

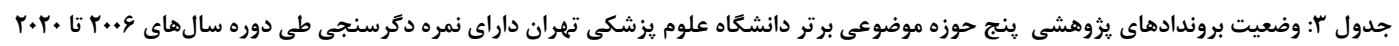

\begin{tabular}{|c|c|c|c|c|c|}
\hline ميانَين نمره & مجرموع نمره & دروهشى دراراى نمره & رسارهد بروندادهاى دره & تئوهشاد كل بروندادهاى در اسكويوس & \\
\hline$V / V$ & r.TAT & $\%$ \% & $\% r v$ & $v \cdot v \Delta$ & بيوشيمى، رُنتيك و زيستشناسى مولكولى \\
\hline r & s499 & $\% \wedge \Delta$ & $\%$ \% & pq.r & داروشناسى، سمشناسى و داروسازى \\
\hline$\Delta$ & GVQV & $\% \wedge \Delta$ & $\%$ ra & raqu & ايمونولوزى و ميكروبشناسى \\
\hline$r / 4$ & Ired & $\% \wedge 1$ & $\%$ r & $r \Delta \cdot V$ & 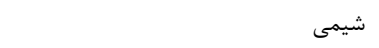 \\
\hline$r$ & 1499 & $\% .94$ & $\%$ \% & T.rT & مهيندسى \\
\hline
\end{tabular}

جدول f: رابطه ميان شاخص نشانهكذارى، توييت و نمره دَّر سنجى با استناد دريافتى در ينج موضوع برتر بروندادهاى يزوهشى دانشكاه علوم يزشكى تهران

\begin{tabular}{|c|c|c|c|c|c|c|}
\hline \multicolumn{2}{|c|}{ تعداد استناد با نمره دكر سنجى } & \multicolumn{2}{|c|}{ تعداد استناد با تعداد توييت } & \multicolumn{2}{|c|}{ تعداد استناد با تعداد نشانه كـــذارى } & \\
\hline 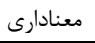 & ضريب همبستكى & معنادارى & ضريب همبستَىى & معنادارى & ضريب همبستىى & \\
\hline$\cdot 1 \cdots$ & $\cdot / / \vee \Delta$ &.$/ \cdot r \cdot$ &.$- / \cdot k r$ & $\cdot / \cdots$ & $.19 \mathrm{~V}$. & بيوشيمى، زنتيكى و زيستشناسى مولكولى \\
\hline$\cdot 1 \cdots$ & $\cdot / r \cdot$ & $\cdot 1 \cdots$ & $-\cdot / 1 \cdot r$ & $\cdot / \cdots$ & $.19 \mathrm{VV}$ & داروشناسى، سمشناسى و داروسازى \\
\hline$\cdot 1 \cdots$ & $\cdot / r T \Delta$ &.$/ 1 F$. & $-\cdot|\cdot f|$ & $\cdot 1 \cdots$ &. $\mid 9 \vee \wedge$ & ايمونولوزى و ميكروبشناسى \\
\hline $.1 \cdot \mu t$ & $\cdot / \cdot \wedge 9$ &.$/ \cdots$ & $-\cdot / 1 \wedge \vee$ & $\cdot / \cdots$ & - /VMG & 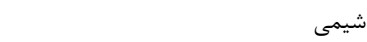 \\
\hline $.1 \cdots$ &.$/$ rat & $\cdot 1 \cdots 1$ &.$/ 111$ & $\cdot 1 \cdots$ & - /NTS & 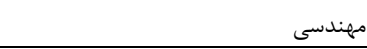 \\
\hline
\end{tabular}




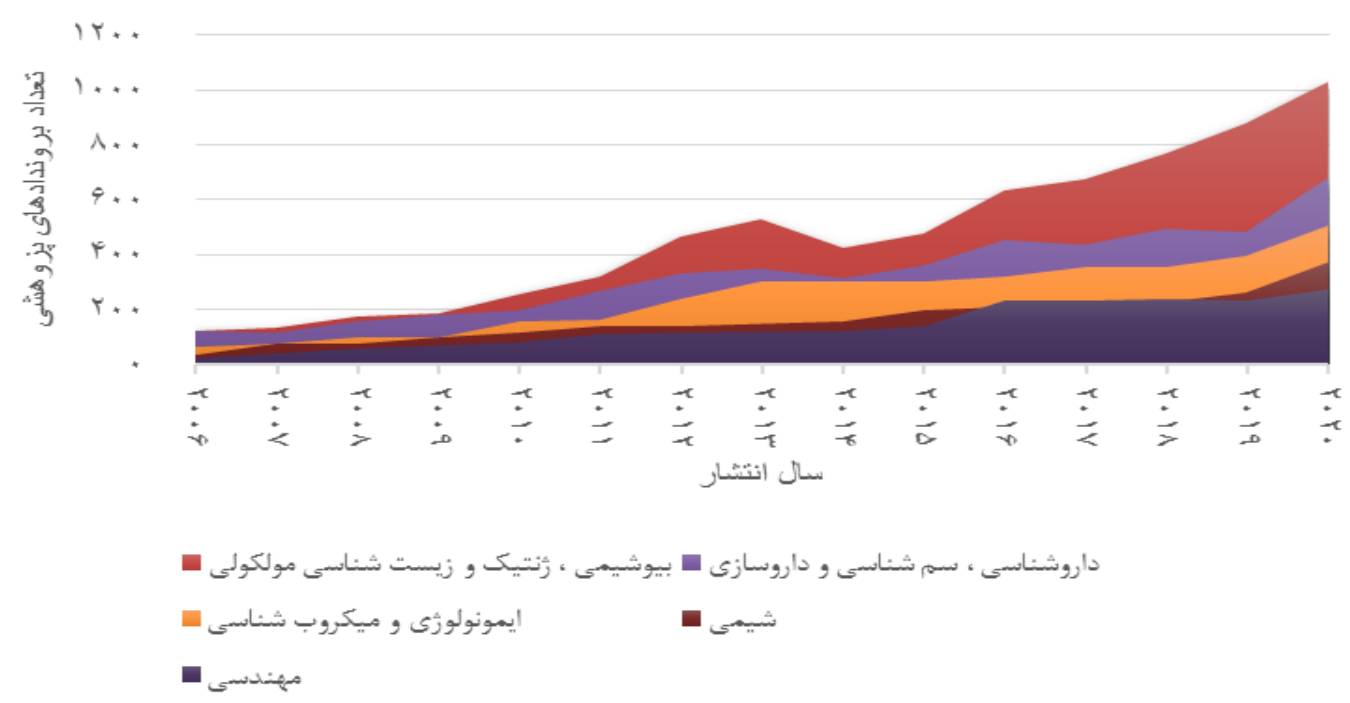

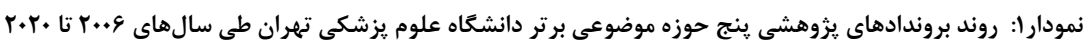

در مجلـههـاى برتــر يـا جــارك اول (Quarter 1: Q1)، حـوزه موضوعى "امهندسى" جايگاه بالايى را در هر سه دوره زمـانى مـورد

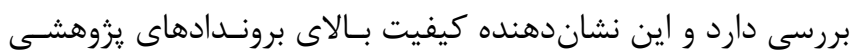

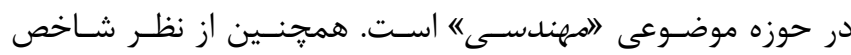

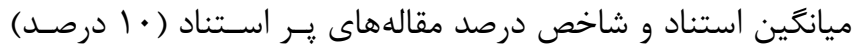

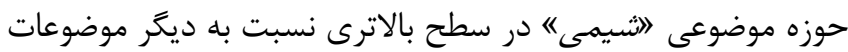

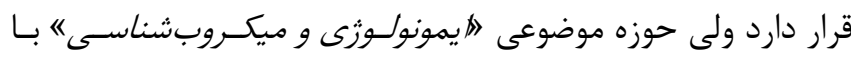

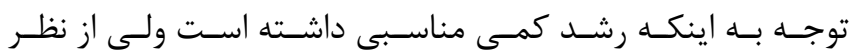
شاخصهاى استنادى در هر سه دوره زمـانى در سـطح يـايينتـرى

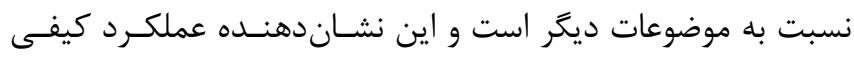
يايين بروندادهاى يزوهشى در ايسن حسوزه موضـوعى اسـت. در ايسن

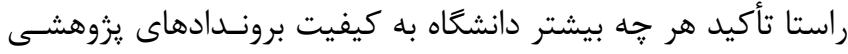
در كنار كميت اين بروندادها از اهميت بسيار زيادى برخوردار است.

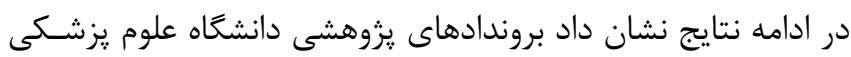

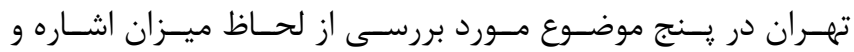

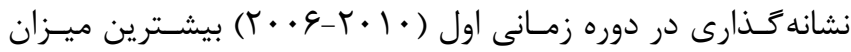
توجه را در رسانه منــلى، تـوييتر و ويتنـت كسـب كردنـد. در دوره

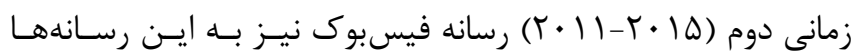

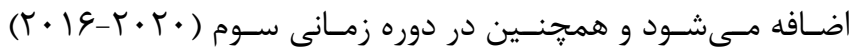
بروندادهاى يزوهشى در رسانه مندلى، توييتر و اخبار بيشترين اشاره

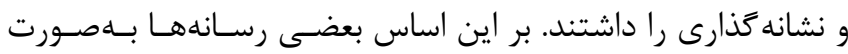

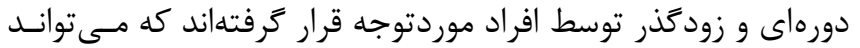

بحث و نتيجه گيرى

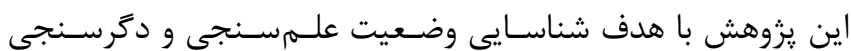

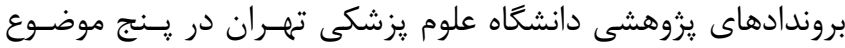

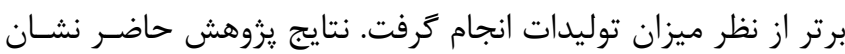
داد سير بروندادهاى يروهشى در ينج موضوع مورد بررسـى در اكثـر

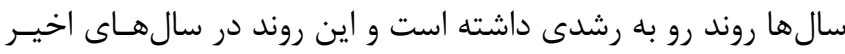
در دو حوزه موضوعى "بيوشيمى، زنتيك و زيستشناسى مولكولى"

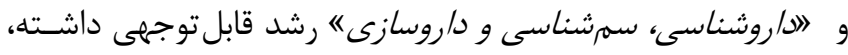

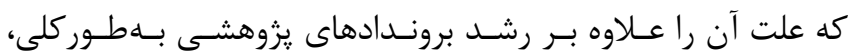
مى توان ناشى از ييشرفتهاى فناورى و تجهيزات در حوزه يزشـكى، تغييرات در سياست گذارى هاى علمى كشور، تلاش بيشتر محققـان، افزايش بودجههاى تحقيقاتى و شكل گيرى سـازمانهـا و مؤسسـات تحقيقاتى ييشرو در اين حوزهها دانسـت. همجنــين برونـدادهاى دو حوزه موضوعى "شيمى" و "مهندسى" در طى جند سال اخير، سير

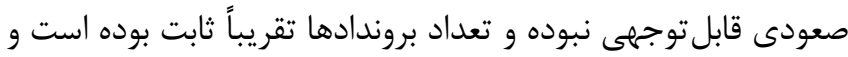

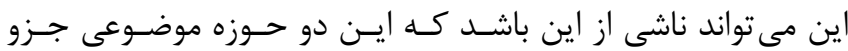
حوزههاى تخصصى رشته يزشكى نيستند و تمايل يزوهشگران براى مشاركت در توليد علم در اين دو حوزه موضوعى كمتر است.

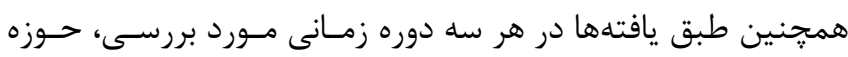
موضـوعى ابيوشـيمى، زنتيـك و زيسـتشناسـى مولكـولى" داراى

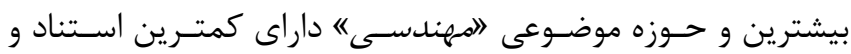
شاخص اج هستند. ولى از نظر شاخص درصد مقالههاى منتشر شده 
عضويت يزوهشــران و اشـتراكَّــارى آثـار آنهـا در رسـانههـاى

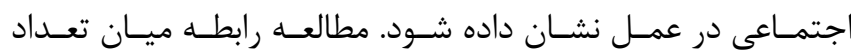

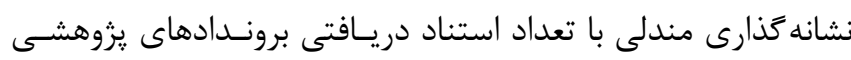

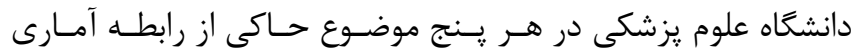

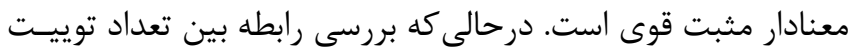

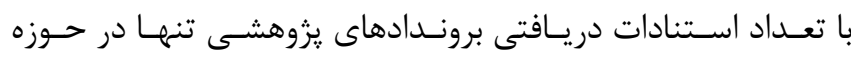

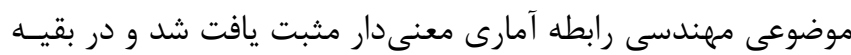

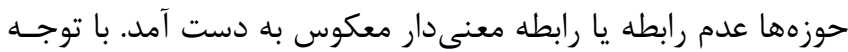

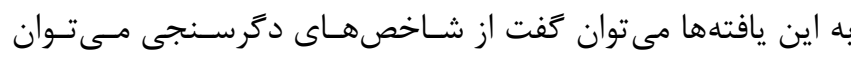

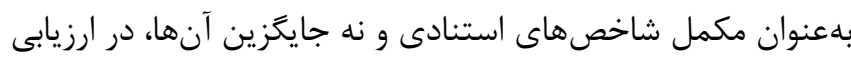

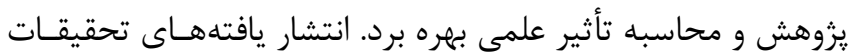

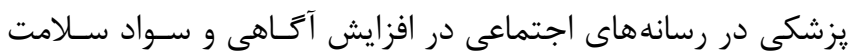

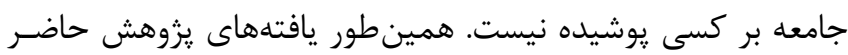

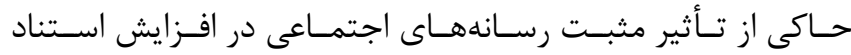

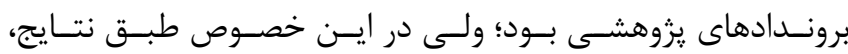

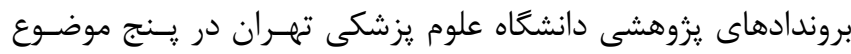
مورد بررسى، حضور مطلوبى در رسانههاى اجتماعى نداشتند و لازم

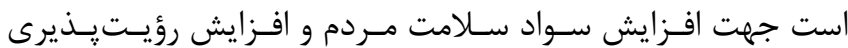

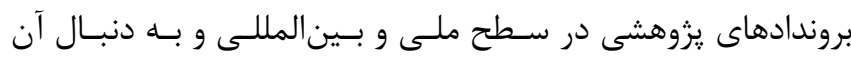
افزايش شاخصهاى اثر كذارى بروندادها اقدامات زير انجام شود:

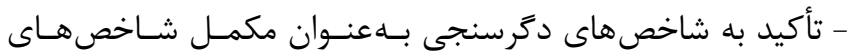

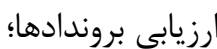

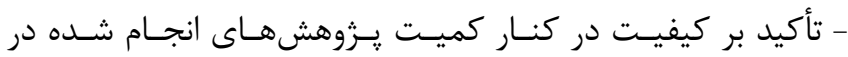

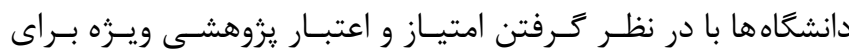
نويسند كان مقالات در مجلههاى برتر؛

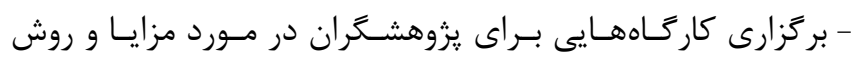

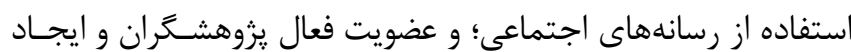

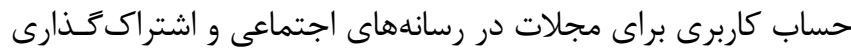

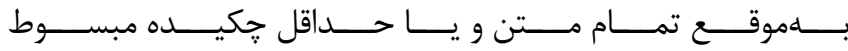
بروندادها در اين رسانهها. (Extended Abstract)

\section{سهم نويسند}

امير قاسميان: استخراج دادهها، نكارش مقاله فرشته نوجوان: تجزيه و تحليل دادهها، نحارش مقاله آرزو دانايىنيا: همكارى در نغارش مقاله نجاله
ناشى از عدم قابليت آن رسانه در طول زمان نسبت به ديكر رسانهها باشد. ولى دو رسانه مندلى و توييتر در تمام سه دوره رسانه محبوب

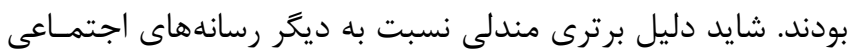

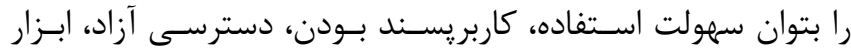

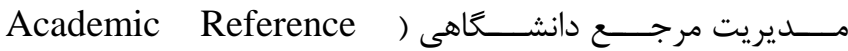
(Management Tool بودن آن و رسانه شناخته شده توسط اكثــ اقشـار جامعـهـ (اعهم از

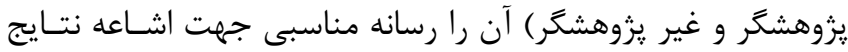

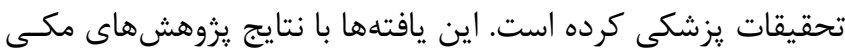

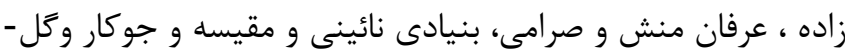

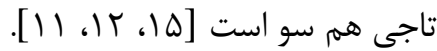

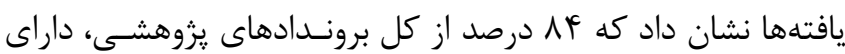

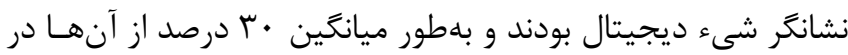

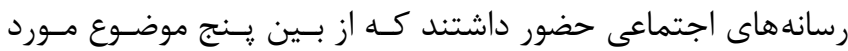

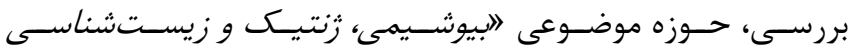

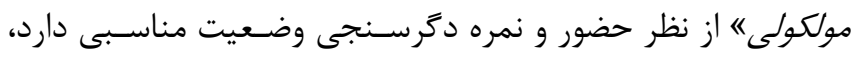

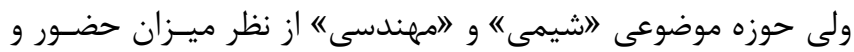

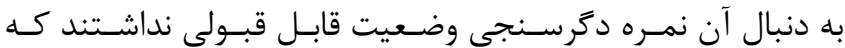
نشان دهنده عدم آشنايى يزوهشكَران اين حوزه از مزيتهاى رداى رسانه-

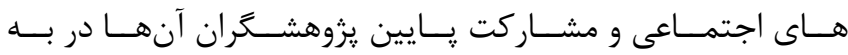

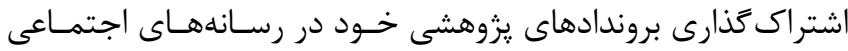

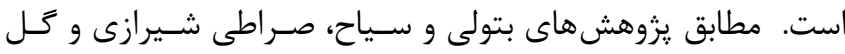

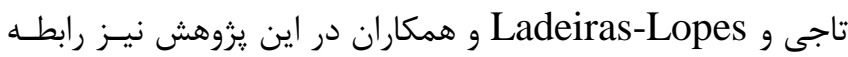
آمارى معنادار مثبت بين نمره دكرسنجى و تعداد استنادها به دست

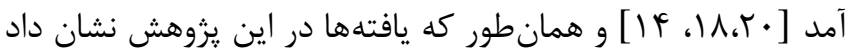

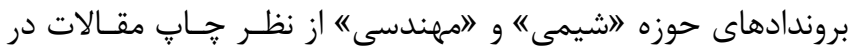

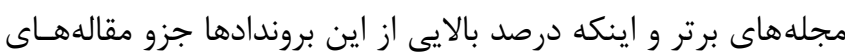

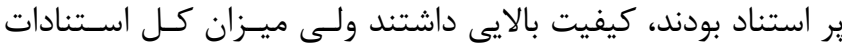

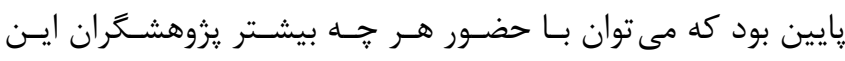

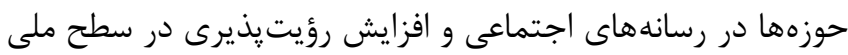
و جهانى ميزان استنادات آنها را افزايش داد و لازمه اين كـار آشـــا

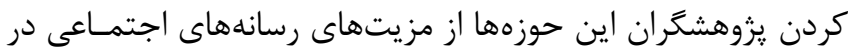

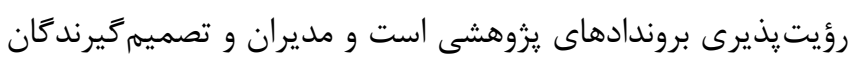

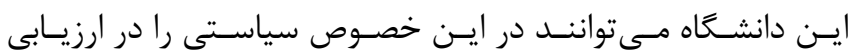

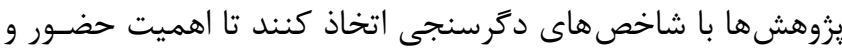




\section{منابع}

1. Norouzi A, Abolghasemi M, Ghahramani M. Exploring barriers to science production from the viewpoint of Shahid Beheshti university faculty members. Journal of New Approach in Educational Administration 2015; 6:77-108 [Persian]

2. Erfanmanesh M, Hosseini E. The quality of international articles of the university of Isfahan during 2006-2015. Quarterly Knowledge and Information Management Journal 2017; 4:31-40 [Persian]

3. Arshadi H, Erfanmanesh $\mathrm{M}$, Salemi N. Visualization and analysis of co-uthorship networks of Shahid Beheshti university researchers in humanities, social sciences and art. Scientometrics Research Journal 2017; 3:15-32 [Persian]

4. Esmaeilpour BM, Batooli Z, Ramezani A, Ranjbar PZ, Ramezani PF. An assessment of altmetrics indicators on citation rate of articles affiliated by Guilan university of medical sciences. Health Information Management 2017; 13:362-372 [Persian]

5. Mansour Kiyaei R, Babolhavaeji F, Nooshinfard F, Soheili F. Evaluating dissemination of knowledege and information science papers in social networks. Scientometrics Research Journal 2018; 4:161-178 [Persian]

6. Erfanmanesh M. The presence of Iranian information science and library science articles in social media: An altmetric study. Journal of Information Processing and Management 2017; 32:349-373 [Persian]

7. Priem J, Taraborelli D, Groth P, Neylon C. Altmetrics: A manifesto. [Internet] 26 October 2010 http://altmetrics.org/manifesto/

8. Waltman L, Costas R. F 1000 recommendations as a potential new data source for research evaluation: A comparison with citations. Journal of the Association for Information Science and Technology 2014; 65:433-445 [DOI:10.1002/asi.23040]

9. Holmberg KJ. Altmetrics for information professionals: Past, present and future. Amsterdam: Elsevier Science, 2015 https://books.google.com/books/about/Altmetrics_for_In formation_Professionals.html?id=GhdiBQAAQBAJ\&so urce $=$ kp_book_description

10. Shahmoradi M, Safaei AA, Tajrishi H, Nazari E, Delaram Z, Zarei Z, et al. The common applications of social networks in healthcare. Health Information Management 2016; 13:243-248 [Persian]

11. Makkizadeh F, Erfanmanes MA, Sarrami F. An altmetric study of medical informatics and health information management articles in social media. Health Information Management 2020; 17:118-124 [Persian]

12. Bonyadi Naeini A, Moghiseh Z. Altmetric study of scientific outputs of Iranian researchers in Coronavirus. Scientometrics Research Journal. 2020 [Persian] [DOI:10.22070/RSCI.2020.13360.1447]

13. Ehtesham H, Sadeghi H, Vahedi Darmian F, Amiri O. Evaluation of altmetrics indicators of Birjand University of Medical Sciences articles listed on the Scopus Database by using the PlumX Tool: A scientometric study. Journal of Birjand University of Medical Sciences 2019; 26:343-352 [Persian]

14. Serati Shirazi M, Goltaji M. An altmetric study on scientific articles of "health literacy" in social media. Payesh 2018; 17:249-256 [Persian] [DOI:20.1001.1.16807626.1397.17.3.4.2]

15. Jowkar A, Goltaji M. Comparative study of selfcitation rate in two Iranian library journals, Faslname-Ye Ketab and Faslname Ketabdary Va Etela'rasany based on PJCR during 1382-1386. Library and Information Science 2010; 13:91-110 [Persian]

16. Wang J, Alotaibi NM, Ibrahim GM, Kulkarni $\mathrm{AV}$, Lozano AM. The spectrum of altmetrics in neurosurgery: The top 100 "trending" articles in neurosurgical journals. World Neurosurgery 2017; 103:883-895.e1 [DOI:10.1016/j.wneu.2017.04.157]

17. Fabiano N, Hallgrimson Z, Kazi S, Salameh JP, Wong S, Kazi A, et al. An analysis of Covid-19 article dissemination by Twitter compared to citation rates. MedRxiv 2020 [DOI:10.1101/2020.06.22.20137505]

18. Ladeiras-Lopes $\mathrm{R}$, Clarke S, Vidal-Perez R, Alexander M, Lüscher TF. Twitter promotion predicts citation rates of cardiovascular articles: A preliminary analysis from the ESC journals randomized study. European Heart Journal 2020; 41:3222-3225 [DOI:10.1093/eurheartj/ehaa211]

19. Janavi E, Nadi-Ravandi S, Batooli Z. Impact of Researchgate on increasing citations and usage counts of hot papers in clinical medicine indexed in Web of Science. Webology 2020; 17:130-139 http://eprints.kaums.ac.ir/5369/

20. Batooli Z, Sayyah M. Measuring social media attention of scientific research on novel coronavirus disease 2019 (Covid-19): An investigation on articlelevel metrics data of dimensions. Research Square 2020 [DOI:10.21203/rs-21980/v1] 